\title{
Formulasi Spray Gel Antioksidan Kombinasi Ekstrak Daun Jambu Air Dan Ekstrak Daun Mangga
}

\author{
Salma Hilmy Rusydi $H^{*}$, Teti Indrawati, Ratna Djamil
}

Program Magister Ilmu Kefarmasian, Fakultas Farmasi, Universitas Pancasila, Jalan Raya Lenteng No.56-80, RT 1 RW 3, Srengseng Sawah, Jagakarsa, Jakarta Selatan, Indonesia, 12640 ${ }^{*}$ E-mail: amaimy9@gmail.com

(Submit 29/11/2021, Revisi 05/02/2022, Diterima 18/02/2022, Terbit 03/03/2022)

\begin{abstract}
Abstrak
Daun jambu air (Syzygium aqueum (Burm.f) Alston) dan daun mangga (Mangifera indica L.) mengandung senyawa polifenol dan flavonoid yang memiliki aktivitas antioksidan. Tujuan penelitian ini untuk mendapatkan aktivitas antioksidan optimum melalui kombinasi ekstrak daun jambu air (EJA), ekstrak daun mangga (EMA) dan menghasilkan sediaan spray gel dengan aktivitas antioksidan optimum serta karakteristiknya. Ekstrak dibuat dengan metode maserasi menggunakan pelarut etanol $70 \%$, uji aktivitas antioksidan ekstrak tunggal serta kombinasinya perbandingan 1:1; 2:1; 1:2 dengan metode DPPH, dikembangkan dalam formula spray gel berdasarkan nilai IC50 kombinasi ekstrak dengan aktivitas antioksidan optimum sebesar 100xIC50; 150xIC50; 200xIC50. Hasil kombinasi ekstrak daun jambu air (EJA) dan ekstrak daun mangga (EMA) memiliki aktivitas antioksidan lebih besar dibandingkan ekstrak tunggalnya antara 5,35-6,42 $\mu \mathrm{g} / \mathrm{mL}$ dengan aktivitas optimum diberikan oleh perbandingan 1:2 dengan nilai IC50 5,35 $\mathrm{g} / \mathrm{mL}$. Aktivitas antioksidan optimum sediaan spray gel dihasilkan oleh formula dengan 200xIC50 yang mengandung 0,107\% kombinasi ekstrak daun jambu air (EJA) dan ekstrak daun mangga (EMA) perbandingan 1:2 dengan nilai IC50 sebesar 27,92 $\mu \mathrm{g} / \mathrm{mL}$, berwarna kuning muda jernih, bau khas ekstrak, homogen, $\mathrm{pH} 5.47 \pm 0.015$, viskositas $1166.67 \pm 57.74 \mathrm{cPs}$, dapat disemprot, stabil dalam penyimpanan selama 3 bulan pada suhu $4^{\circ} \pm 2^{\circ} \mathrm{C}$ dan $25^{\circ} \pm 2^{\circ} \mathrm{C}$, bersifat iritasi ringan pada kulit kelinci dipengaruhi oleh komponen formula yang menimbulkan resiko iritasi.
\end{abstract}

Kata kunci: Syzygium aqueum, Mangifera indica L, Kombinasi Ekstrak, Spray Gel, Antioksidan 


\section{Pendahuluan}

Kandungan senyawa fitokimia seperti polifenol dan flavonoid dapat dimanfaatkan sebagai antioksidan untuk menetralisir stress oksidatif yang dapat menyebabkan penurunan fungsi kulit salah satunya penuaan dini. Kandungan tersebut tersebar meluas pada tanaman salah satunya pada bagian daun (1). Daun tanaman jambu air (Syzygium aqueum (Burm.f) Alston) telah dilaporkan mengandung senyawa fenol dan flavonoid yang memiliki aktivitas antioksidan (2). Aktivitas antioksidan ekstrak daun jambu air (Syzygium aqueum (Burm.f) Alston) yang diekstraksi dengan pelarut 96\% dilaporkan memiliki aktivitas antioksidan sebesar 10,01 ppm (3). Daun tanaman mangga (Mangifera indica L.) telah diidentifikasi mengandung mangiferin sebagai salah satu golongan polifenol yang memberikan aktivitas antioksidan (4). Aktivitas antioksidan ekstrak daun mangga (Mangifera indica L.) yang diekstraksi dengan etanol 96\% dilaporkan memiliki aktivitas antioksidan sebesar 11,17 ppm (5).

Aktivitas antioksidan ekstrak tanaman dapat dikembangkan untuk mendapatkan aktivitas yang baru melalui penggunaan pelarut etanol berdasarkan tingkat kepolaran yang lebih tinggi untuk menarik senyawa yang bersifat polar seperti flavonoid dalam proses ekstraksi (6). Selain itu, kombinasi ekstrak atau campuran ekstrak dilaporkan sebagai cara untuk mengurangi kebutuhan jumlah dosis ekstrak yang diperlukan dan menghasilkan aktivitas optimum (7). Pada penelitian ini ekstrak daun jambu air ekstrak daun mangga dibuat dengan menggunakan pelarut etanol $70 \%$ yang memiliki tingkat kepolaran lebih tinggi dibandingkan dengan etanol $96 \%$ dan dikombinasikan dalam perbandingan $1: 1 ; 2: 1$ dan $1: 2$ untuk mendapatkan aktivitas antioksidan yang optimum dibanding ekstrak tunggalnya sehingga dapat dimanfaatkan dalam sediaan kosmetik untuk mencegah penuaan dini pada kulit.

Spray gel merupakan sediaan kosmetik dengan kelebihan diantaranya tingkat paparan langsung jari tangan yang rendah dibanding sediaan lain, praktis, aman, mudah dicuci, mengurangi resiko sediaan teroksidasi oleh udara diakibatkan buka tutup wadah (8). Pada penelitian sebelumnya penggunaan polimer seperti Hidroksi Propil Metil Selulosa (HPMC) dan Hidroksi Etil Selulosa (HEC) pada konsentrasi 0,25\% dapat menghasilkan sediaan spray gel dan stabil pada penyimpanan suhu $25^{\circ}-27^{\circ} \mathrm{C}$ sebagai antioksidan namun penelitian tersebut tidak dilakukan uji iritasi (9). Pada penelitian ini dilakukan pengembangan formula spray gel dengan modifikasi terhadap bahan aktif sebagai antioksidan yaitu ekstrak daun jambu air dan ekstrak daun mangga sebagai antioksidan serta dilakukan evaluasi termasuk uji iritasi.

\section{Metode}

\section{Alat}

Timbangan analitik (Nagata E 15000), gelas ukur (Pyrex), gelas piala (Pyrex), rotary evaporator (IKA) batang pengaduk, mikropipet, spektrofotometer UV-Vis (Simazu), homogenizer, pH meter, oven, cawan penguap, cawan porselen, viskometer (Brookfield tipe RV). 


\section{Bahan}

Daun jambu air (Syzygium aqueum (Burm.f) Alston) tua berwarna hijau kekuningan, daun mangga (Mangifera indica L) muda berwarna hijau muda, etanol 70\% (PT. Palapa Muda Perkasa), DPPH (Qlab-FFUP), Metanol (Qlab FFUP), asam askorbat (Palapa Muda Perkasa), HPMC (Palapa Muda Perkasa), HEC (Palapa Muda Perkasa), propilen glikol (Palapa Muda Perkasa), metil paraben (Brataco), dan aquadest.

\section{Prosedur Rinci}

1. Determinasi Tanaman

Bagian tanaman ranting muda, daun, dan buah jambu air dan mangga diidentifikasi di Pusat Penelitian Konservasi Tumbuhan dan Kebun Raya, LIPI, Bogor, Jawa Barat.

2. Pembuatan Ekstrak

Serbuk simplisia dimaserasi dalam pelarut etanol 70\% (1:10) selama 3×24 jam pada suhu ruangan $15-30^{\circ} \mathrm{C}$, diaduk sesekali. Hasil filtrat ekstraksi diuapkan dengan menggunakan rotary evaporator pada suhu $40-50^{\circ} \mathrm{C}$ hingga diperoleh ekstrak kental kemudian dihitung rendemen ekstrak dan dievaluasi karakteristik organoleptik meliputi bentuk, warna, bau dan rasa.

3. Skrining Fitokimia

Ekstrak daun jambu air (EJA) dan ekstrak daun mangga (EMA) diuji kandungan fitokimia meliputi flavovoid, fenol, alkaloid, tanin dan saponin (10).

4. Uji Aktivitas Antioksidan Ekstrak

Uji aktivitas antioksidan ekstrak daun jambu air (EJA) dan ekstrak daun mangga (EMA) dilakukan mengikuti metode Kristiningrum (2018) dengan modifikasi. Larutan uji induk dibuat dalam konsentrasi $3000 \mu \mathrm{g} / \mathrm{mL}$ untuk ekstrak tunggal dan konsentrasi $1500 \mu \mathrm{g} / \mathrm{mL}$ untuk ekstrak kombinasi 1:1; 2:1 dan 1:2 dalam jumlah bobot total ekstrak sebanyak $30 \mathrm{mg}$ yang dilarutkan dalam metanol sebanyak $10 \mathrm{~mL}$ dan $20 \mathrm{~mL}$ (11). Perbandingan bobot kombinasi ekstrak daun jambu air (Syzygium aqueum (Burm.f) Alston) dan ekstrak daun mangga (Mangifera indica L.) sebesar 1:1; 2:1 dan 1:2. Formula bobot kedua ekstrak dapat dilihat pada Tabel 1.

Tabel 1 Perbandingan Bobot Ekstrak Daun Jambu Air dan Ekstrak Daun Mangga

\begin{tabular}{cccc}
\hline \multicolumn{2}{c}{ Bobot ekstrak (mg) } & $\begin{array}{c}\text { Perbanding } \\
\text { an } \\
\text { EJA:EMA }\end{array}$ & Keterangan \\
\hline 30 & EMA & $1: 0$ & Tunggal \\
- & - & $0: 1$ & Tunggal \\
15 & 30 & $1: 1$ & Kombinasi \\
20 & 15 & $2: 1$ & Kombinasi \\
10 & 10 & $1: 2$ & Kombinasi \\
\hline
\end{tabular}

Keterangan $: \mathrm{EJA}=$ Ekstrak Daun Jambu Air, EMA $=$ Ekstrak Daun Mangga 
Pengukuran serapan larutan uji dipipet sebanyak $5 \mu \mathrm{L}, 10 \mu \mathrm{L}, 15 \mu \mathrm{L}, 20 \mu \mathrm{L}, 25 \mu \mathrm{L}, 30$ $\mu \mathrm{L}$, dimasukan kedalam labu tentukur $5 \mathrm{~mL}$, ditambahkan $1 \mathrm{ml}$ DPPH konsentrasi 160 $\mu \mathrm{g} / \mathrm{mL}$, diencerkan dengan metanol hingga tanda batas dan dikocok hingga homogen. Campuran larutan diinkubasi pada suhu $37^{\circ} \mathrm{C}$ selama 30 menit kemudian diukur serapannya dengan spektrofotometer UV-Vis pada panjang gelombang maksimum yaitu 515,6 nm. Nilai IC50 dihitung berdasarkan persen inhibisi antara konsentrasi dan penentuan persamaan regersi $y=B x+A$.

\section{Pembuatan Spray Gel}

Formula spray gel dapat dilihat pada Tabel 2

Tabel 2 Formula Spray Gel Kombinasi Ekstrak Daun Jambu Air dan Ekstrak Daun Mangga

\begin{tabular}{|c|c|c|c|c|c|}
\hline Nama Bahan & \multicolumn{4}{|c|}{ Formula $(\% ; b / b)$} & Fungsi \\
\hline $\begin{array}{l}\text { Ekstrak Daun Jambu Air } \\
\text { Ekstrak Daun Mangga }\end{array}$ & - & $100 x \mathrm{IC} 50$ & $150 \times 1 C 50$ & $200 \times 1 C 50$ & $\begin{array}{c}\text { Bahan } \\
\text { Aktif }\end{array}$ \\
\hline Vitamin C & 0,05 & - & - & - & $\begin{array}{c}\text { Bahan } \\
\text { Aktif }\end{array}$ \\
\hline HPMC & 0,25 & 0,25 & 0,25 & 0,25 & Basis Gel \\
\hline HEC & 0,25 & 0,25 & 0,25 & 0,25 & Basis Gel \\
\hline Propilenglikol & 15 & 15 & 15 & 15 & Pelarut \\
\hline Metil Paraben & 0,18 & 0,18 & 0,18 & 0,18 & Pengawet \\
\hline Aquadest ad & 100 & 100 & 100 & 100 & Pelarut \\
\hline
\end{tabular}

Spray gel dibuat menggunakan prinsip pelarutan dan pencampuran. Basis gel dibuat dengan masing-masing mendispersikan HPMC dan HEC ke dalam air panas (60-70ㄷ) sebanyak 20 kali berat HPMC dan HEC, didiamkan hingga mengembang selama 24 jam. Campuran ekstrak kombinasi daun jambu air dan daun mangga dilarutkan dengan sebagian propilenglikol dan aquadest (fase air). Metil paraben dilarutkan dalam sebagian propilenglikol. Larutan ekstrak dimasukan ke dalam basis gel sedikit demi sedikit, diaduk hingga homogen menggunakan homogenizer, ditambah larutan metil paraben, ditambahkan akuades hingga 100\% diaduk sampai homogen.

\section{Evaluasi Spray Gel}

\section{a. Organoleptik}

Pemeriksaan dilakukan secara visual terhadap bentuk, warna dan bau.

b. Homogenitas

Dilakukan dengan mengoleskan sediaan pada kaca preparat, diamati ada tidaknya partikel atau zat yang tidak homogen atau tercampur (9).

c. $\mathrm{pH}$

Uji pH spray gel dengan menggunakan $\mathrm{pH}$ meter (Hanna) yang telah dikalibrasi.

d. Viskositas

Uji kekentalan atau viskositas spray gel dengan menggunakan viskometer Broofield RV, spindel nomor 2 dengan kecepatan 1 rpm (9).

e. Kondisi Semprotan

Uji dilakukan untuk mengetahui kondisi semprotan dari sediaan spray gel (12). 


\section{f. Uji Aktivitas Antioksidan}

Spray gel dievaluasi aktivitas antioksidannya kembali dengan metode DPPH

g. Uji Stabilitas

Uji stabilitas dilakukan pada formula dengan aktivitas antioksidan optimum atau terbaik, dievaluasi pada suhu $4^{\circ} \pm 2^{\circ} \mathrm{C}$ dan $25^{\circ} \pm 2^{\circ} \mathrm{C}$ tiap 14 hari selama 3 bulan meliputi organoleptik, pH dan viskositas (8).

h. Uji Iritasi

Uji dilakukan terhadap kelinci jantan New Zealand yang telah diaklimitasi selama 7 hari, formula dengan aktivitas antioksidan optimum dioles pada derah punggung kelinci yang telah dicukur, ditutup menggunakan plester non-iritan, diamati respon eritema dan udema selama 24 jam, 48 jam dan 72 jam (13). Uji dilakukan berdasarkan persetujuan kaji etik dari Komisi Etik Penelitian Kesehatan Universitas Muhammadiyah Prof. DR. HAMKA No.02/20.12/0801.

Perhitungan indeks iritasi menggunakan rumus sebagai berikut (13):

$$
\text { Indeks iritasi primer }=\frac{\mathrm{A}-\mathrm{B}}{\mathrm{C}}
$$

Keterangan : A : Jumlah skor eritema dan udema seluruh titik pengamatan sampel pada jam ke 24, 48 dan 72 dibagi jumlah pengamatan

B : Jumlah skor eritema dan udema seluruh titik pengamatan kontrol pada jam ke 24, 48 dan 72 dibagi jumlah pengamatan

C : Jumlah hewan

\section{Hasil}

Hasil Identifikasi Tanaman

Berdasarkan surat keterangan No.B-1541/IPH.3/KS/XI/2020 menyatakan tanaman yang digunakan adalah jambu air spesies (Syzygium aqueum (Burm.f) Alston), familia Myrtaceae. Mangga (Mangifera indica L.), familia Anacardiaceae.

\section{Hasil Ekstrak}

Hasil ekstrak daun jambu air (EJA) dan ekstrak daun mangga (EMA) diperoleh berupa ekstrak kental, berwarna coklat kekuningan, berbau khas tanaman dan tidak berasa. Hasil rendemen ekstrak dapat dilihat pada Tabel 3.

Tabel 3 Hasil Rendemen Ekstrak

\begin{tabular}{ccccc}
\hline Sampel & $\begin{array}{c}\text { Bobot } \\
\text { Sampel (g) }\end{array}$ & $\begin{array}{c}\text { Bobot } \\
\text { Simplisia (g) }\end{array}$ & $\begin{array}{c}\text { Bobot } \\
\text { Ekstrak (g) }\end{array}$ & $\begin{array}{c}\text { Rendemen } \\
(\%)\end{array}$ \\
\hline EJA & 1000,00 & 400,00 & 148,20 & 37,05 \\
EMA & 1000,00 & 400,20 & 139,70 & 34,90 \\
\hline
\end{tabular}


Hasil Skining Fitokimia

Hasil skrining fitokimia ekstrak daun jambu air (EJA) dan ekstrak daun mangga (EMA) dapat dilihat pada Tabel 4.

Tabel 4 Fitokimia Ekstrak

\begin{tabular}{ccc}
\hline Pemeriksaan & EJA & EMA \\
\hline Flavonoid & + & + \\
Fenol & + & + \\
Alkaloid & + & + \\
Tanin & + & + \\
Saponin & + & + \\
\hline
\end{tabular}

Keterangan : (+) Terdeteksi, (-) Tidak Terdeteksi

Hasil Aktivitas Antioksidan

Hasil aktivitas antioksidan ekstrak daun jambu air (EJA) dan ekstrak daun mangga (EMA) tunggal, kombinasi serta sediaan spray gel dapat dilihat pada Gambar 1 dan 2.

\section{Nilai IC50 Ekstrak}

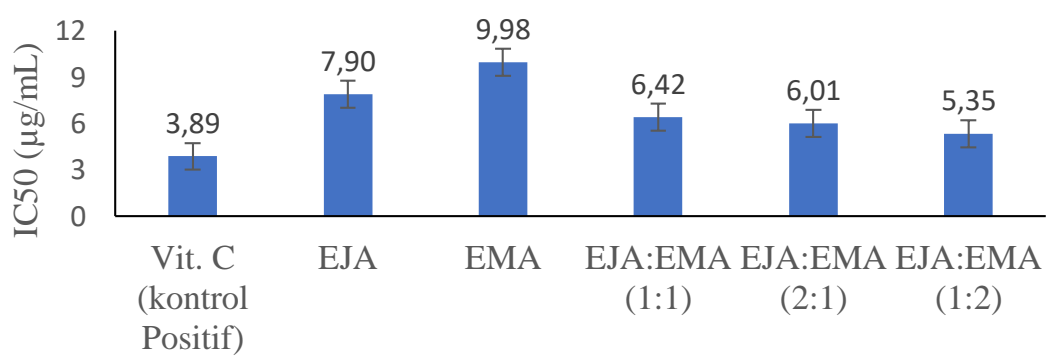

Gambar 1. Diagram Nilai IC50 Ekstrak Daun Jambu Air dan Ekstrak Daun Mangga Tunggal dan Kombinasi $(n=3)$

\section{Nilai IC50 Spray Gel}

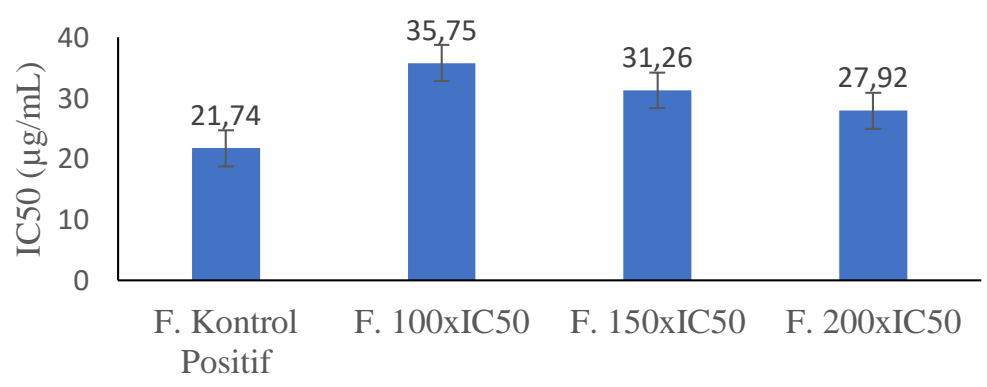

Gambar 2. Diagram Nilai IC50 Spray Gel Kombinasi Ekstrak Daun Jambu Air dan Ekstrak Daun Mangga 1:2 ( $n=3)$ 
Hasil Karakteristik Spray Gel

Hasil pengamatan organoleptik spray gel kombinasi ekstrak daun jambu air (EJA) dan ekstrak daun mangga (EMA) berupa cairan kental seperti gel, berwarna kuning muda jernih, berbau khas ekstrak. Karakteristik lainya meliputi homogenitas, $\mathrm{pH}$, viskositas dan kondisi semprotan dapat dilihat pada Tabel 5.

Tabel 5 Karakteristik Spray Gel Kombinasi Ekstrak Daun Jambu Air dan Ekstrak Daun Mangga $(\mathrm{n}=3)$

\begin{tabular}{ccccc}
\hline Formula & Homogenitas & $\mathrm{pH}$ & Viskositas $(\mathrm{cPs})$ & $\begin{array}{c}\text { Kondisi } \\
\text { Semprotan }\end{array}$ \\
\hline F. Kontrol & Homogen & $3.50 \pm 0.015$ & $967.67 \pm 57.74$ Dapat disemprot \\
F.100xIC50 & Homogen & $5.46 \pm 0.015$ & $1100 \pm 100$ & Dapat disemprot \\
F. 150xIC50 & Homogen & $5.45 \pm 0.017$ & $1133.33 \pm 57.74$ Dapat disemprot \\
F. 200xIC50 & Homogen & $5.47 \pm 0.015$ & $1166.67 \pm 57.74$ Dapat disemprot \\
\hline
\end{tabular}

Hasil Pengamatan Stabilitas Penyimpanan Suhu $4^{\circ} \pm 2^{\circ} \mathrm{C}$ dan $25^{\circ} \pm 2^{\circ} \mathrm{C}$

Hasil pengamatan stabilitas organoleptik spray gel dilakukan pada formula 200xIC50 dengan aktivitas antioksidan optimum yang mengandung 0,107\% kombinasi ekstrak daun jambu air (EJA) dan ekstrak daun mangga (EMA) perbandingan 1:2 bahwa sediaan tetap stabil berbentuk cairan kental seperti gel, tidak mengalami perubahan warna dan bau. Hasil stabilitas pH dan viskositas dapat dilihat pada Gambar 3 dan 4.

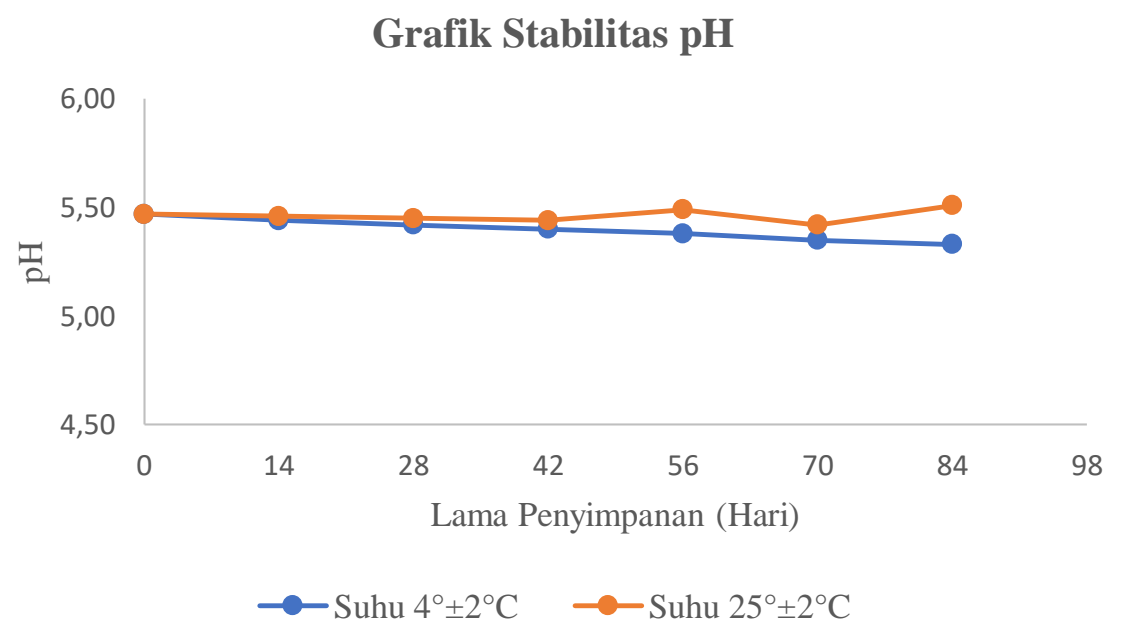

Gambar 3. Grafik pH Suhu $4^{\circ} \pm 2^{\circ} \mathrm{C}$ dan $25^{\circ} \pm 2^{\circ} \mathrm{C}$ 


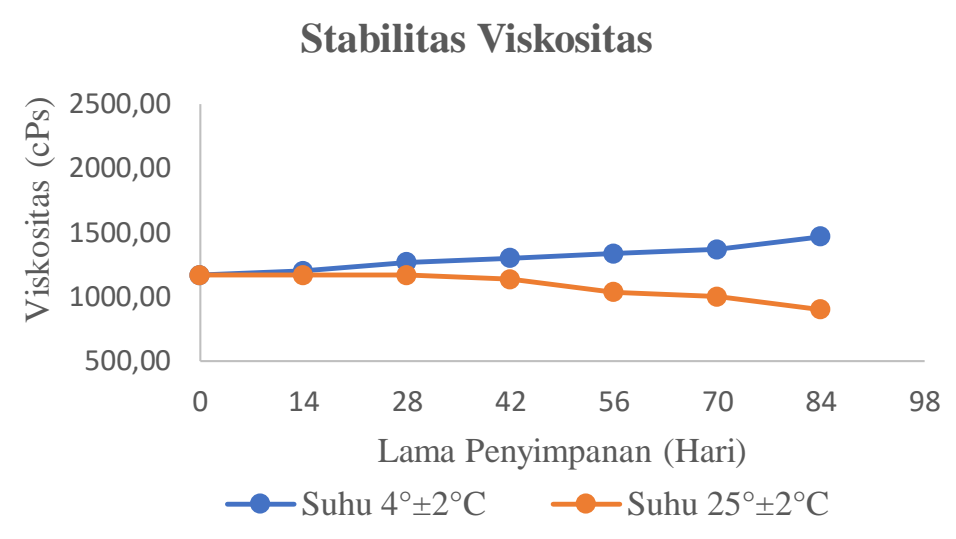

Gambar 4. Grafik Viskositas (cPs) Suhu $4^{\circ} \pm 2^{\circ} \mathrm{C}$ dan $25^{\circ} \pm 2^{\circ} \mathrm{C}$

Hasil Pengamatan Uji Iritasi

Hasil pengamatan uji iritasi spray gel dilakukan pada formula 200xIC50 dengan aktivitas antioksidan optimum yang mengandung $0,107 \%$ kombinasi ekstrak daun jambu air (EJA) dan ekstrak daun mangga (EMA) perbandingan 1:2 memiliki sifat iritasi ringan yang dapat dilihat pada Tabel 6 .

Tabel 6 Uji Iritasi Spray Gel $(\mathrm{n}=3)$

\begin{tabular}{ccccccccc}
\hline \multirow{2}{*}{$\begin{array}{c}\text { Waktu } \\
\text { (Jam) }\end{array}$} & \multicolumn{1}{c}{ Kontrol } & \multicolumn{1}{c}{ Area 1 } & \multicolumn{2}{c}{ Area 2 } & \multicolumn{2}{c}{ Area 3 } \\
& $\mathrm{E}$ & $\mathrm{U}$ & $\mathrm{E}$ & $\mathrm{U}$ & $\mathrm{E}$ & $\mathrm{U}$ & $\mathrm{E}$ & $\mathrm{U}$ \\
\hline 24 & 0 & 0 & 0 & 0 & 0 & 0 & 0 & 0 \\
48 & 1 & 0 & 2 & 0 & 1 & 0 & 0 & 0 \\
72 & 2 & 0 & 2 & 0 & 1 & 0 & 2 & 0 \\
Total & 3 & 0 & 4 & 0 & 2 & 0 & 2 & 0 \\
Skor & & & & & & & \\
Indeks & & & \multicolumn{1}{c}{1,67 (Iritasi Ringan) } \\
Iritasi & & & & \\
\hline
\end{tabular}

Keterangan : $\mathrm{E}=$ Eritema, $\mathrm{U}=$ Udema

Kriteria indeks iritasi (13) : 0,0-0,4 (Iritasi Sangat Ringan)

$$
\begin{aligned}
& \text { 0,5-1,9 (Iritasi Ringan) } \\
& 2,0-4,9 \text { (Iritasi Sedang) } \\
& 5,0-8,0 \text { (Iritasi Kuat) }
\end{aligned}
$$

\section{Pembahasan}

Ekstrak daun jambu air (EJA) dan ekstrak daun mangga (EMA) diperoleh menggunakan pelarut etanol $70 \%$ dengan metode maserasi. Hasil rendemen ekstrak daun jambu air (EJA) dan ekstrak daun mangga (EMA) lebih besar dibanding penelitian sebelumnya dengan menggunakan etanol $96 \%$ yaitu sebesar $37,05 \%$ dan $34,90 \%$ (3). 
Penggunaan pelarut etanol $70 \%$ pada proses ekstraksi dapat menarik senyawa bersifat polar seperti polifenol dan flavonoid lebih baik dibanding etanol $96 \%$ yang terdeteksi pada ekstrak daun jambu air (EJA) dan ekstrak daun mangga (EMA) (Tabel 4). Selain pelarut, faktor lainnya dalam proses ekstraksi seperti suhu dan pengadukan dapat mempengaruhi hasil rendemen ekstak (14). Aktivitas antioksidan ekstrak daun jambu air (EJA) dan ekstrak daun mangga (EMA) tunggal dan kombinasinya memiliki nilai IC50 lebik baik atau lebih tinggi dibanding hasil penelitian sebelumnya oleh Auliasari (2016) dan Rahmiyani (2016) menggunakan pelarut ekstraksi etanol 96\%. Menurut Hikmawanti (2021) hasil aktivitas antioksidan ekstrak dikaitkan terhadap tingkat polaritas pelarut ekstraksi yang digunakan (6). Hasil uji aktivitas antioksidan kombinasi ekstrak daun jambu air (EJA) dan ekstrak daun mangga (EMA) memiliki nilai IC50 yang jauh lebih besar dibandingkan ekstrak tunggalnya dengan nilai IC50 5,35-6,42 $\mu \mathrm{g} / \mathrm{mL}$ dalam jumlah dosis yang lebih rendah, hal tersebut menunjukan adanya sifat sinergis kombinasi ekstrak daun jambu air (EJA) dan ekstrak daun mangga (EMA) sebagai antioksidan (7).

Pembuatan spray gel dikembangkan dengan menggunakan kombinasi ekstrak daun jambu air (EJA) dan ekstrak daun mangga (EMA) sebagai bahan aktif dengan variasi konsenstrasi sebesar 100xIC50, 150xIC50 dan 200xIC50 berdasarkan hasil IC50 kombinasi terbaik atau optimum yang diberikan pada perbandingan kombinasi ekstrak 1:2 dengan nilai IC50 5,35 $\mu \mathrm{g} / \mathrm{mL}$. Formula kombinasi ekstrak daun jambu air (EJA) dan ekstrak daun mangga (EMA) dengan 100xIC50 sebesar 0,05\%, 150xIC50 sebesar $0,08 \%$ dan $200 \times$ IC50 sebesar $0,107 \%$. Spray gel memiliki karakteristik fisika kimia yang baik meliputi karakteristik organoleptik berbentuk cairan kental, berwarna kuning muda jernih, bau khas ekstrak, homogen, memiliki pH 5,46-5,47, viskositas 1100-1166,67 cPs, dapat disemprotkan dengan mudah dan memiliki aktivitas antioksidan dengan nilai IC50 antara $27,92-35,75 \mu \mathrm{g} / \mathrm{mL}$.

Formula spray gel 100xIC50, 150xIC50, 200xIC50 memiliki aktivitas antioksidan dengan nilai IC50 antara $27,92-35,75 \mu \mathrm{g} / \mathrm{mL}$ dengan aktivitas optimum dimiliki oleh formula dengan 200xIC50 sebesar 27,92,35 $\mu \mathrm{g} / \mathrm{mL}$. Aktivitas antioksidan mengalami penurunan setelah diformulasikan dalam bentuk spray gel terhadap nilai IC50 kombinasi ekstrak daun jambu air (EJA) dan ekstrak daun mangga (EMA) optimum yaitu $5,35 \mu \mathrm{g} / \mathrm{mL}$. Penurunan terhadap nilai IC50 disebabkan oleh berbagai macam faktor fisiko kimia seperti cahaya, oksigen dan cemaran logam selama proses pembuatan spray gel berlangsung (15).

Formula dengan 200xIC50 yang memiliki aktivitas antioksidan optimum dengan konsentrasi 0,107\% kombinasi ekstrak daun jambu air (EJA) dan ekstrak daun mangga (EMA) 1:2 selama penyimpanan 3 bulan pada suhu $4^{\circ} \pm 2^{\circ} \mathrm{C}$ dan $25^{\circ} \pm 2^{\circ} \mathrm{C}$ tidak mengalami perubahan yang mencolok terhadap bentuk, warna dan bau sediaan. $\mathrm{pH}$ formula 200xIC50 masih dalam rentang pH kulit yaitu diantara 4,5-6,5 sehingga sediaan dapat diaplikasikan pada kulit, viskositas diantara 900-1466,5 cPs (8). Menurut Puspita (2020) viskositas spray gel direntang 500-5000 cPs, viskositas kurang dari 500 cPs sediaan akan mudah dikeluarkan dari aplikator semprot dan jika lebih dari 5000 cPS akan sulit dikeluarkan dari aplikator semprot (8). 
Hasil pengamatan uji iritasi dengan metode draize test menunjukan formula 200xIC50 bersifat iritasi ringan pada kulit kelinci. Faktor penyebab iritasi disebabkan karna adanya kontak alergen (16). Penelitian Kurniasari (2020) menunjukan penggunaan HPMC konsentrasi $5 \%$ tidak menimbulkan resiko iritasi (17). Air dan propilenglikol merupakan komponen yang memiliki konsentrasi tinggi $>15 \%$ dalam formula spray gel. Menurut Yuliani (2016), air tidak memiliki potensi iritasi atau bersifat non-iritan sehingga tidak dapat menimbulkan iritasi (18). Penggunaan propilenglikol dalam formula kosmetik sebagai humektan dilaporkan merupakan bahan yang dapat menimbulkan resiko iritasi dalam beberapa tahun terakhir (19). Menurut beberapa penelitian uji iritasi dengan metode draize test memiliki kelemahan yaitu struktur epidermis antara kulit kelinci dan manusia berbeda sehingga perlu dilakukan pengujian lebih lanjut terhadap kulit manusia (20).

\section{Kesimpulan}

Aktivitas antioksidan optimum kombinasi ekstrak daun jambu air (EJA) dan ekstrak daun mangga (EMA) dihasilkan oleh perbandingan 1:2 dengan nilai IC50 5,35 $\mu \mathrm{g} / \mathrm{mL}$. Aktivitas antioksidan optimum spray gel dihasilkan oleh formula dengan 200xIC50 yang mengandung $0,107 \%$ kombinasi ekstrak daun jambu air (EJA) dan ekstrak daun mangga (EMA) 1:2 dengan nilai IC50 27,92 $\mu \mathrm{g} / \mathrm{mL}$, berwarna kuning muda jernih, bau khas ekstrak, homogen, $\mathrm{pH} 5.47 \pm 0.015$, viskositas $1166.67 \pm 57.74 \mathrm{cPs}$, dapat disemprot, stabil dalam penyimpanan selama 3 bulan pada suhu $4^{\circ} \pm 2^{\circ} \mathrm{C}$ dan $25^{\circ} \pm 2^{\circ} \mathrm{C}$, bersifat iritasi ringan pada kulit kelinci dipengaruhi oleh komponen formula yang menimbulkan resiko iritasi.

\section{Daftar Pustaka}

1. Luo J, Si H, Jia Z, Liu D. Dietary anti-aging polyphenols and potential mechanisms. Antioxidants. 2021;10(2):1-20.

2. Anggrawati PS, Ramadhania ZM. Kandungan Senyawa Kimia dan Bioaktivitas dari Jambu Air (Syzygium aqueum Burn. f. Alston). Farmaka Suplemen. 2016;14(2):331-44.

3. Auliasari N, Gozali D, Santiani A. Formulasi Emulgel Ekstrak Daun Jambu Air ( Syzygium aqueum ( Burm . f .) Alston ) sebagai Antioksidan. J Farm Bahari. 2016;7(2):1-11.

4. Mahdiyah LLZT, Muhtadi A, Nur Hasanah A. Teknik Isolasi dan Penentuan Struktur Mangiferin: Senyawa Aktif dari Tanaman Mangga (Mangifera indica L.). Maj Farmasetika. 2020;5(4):167-79.

5. Rahmiyani I, Nurdianti L. Aktivitas Antioksidan Ekstrak Daun Mangga Mangifera Indica L. Var.Gedong Menggunakan Metode Dpph. J Kesehat Bakti Tunas Husada J IImu-ilmu Keperawatan, Anal Kesehat dan Farm. 2016;16(1):17.

6. Hikmawanti NPE, Fatmawati S, Asri AW. The effect of ethanol concentrations as the extraction solvent on antioxidant activity of Katuk (Sauropus androgynus (L.) Merr.) leaves extracts. IOP Conf Ser Earth Environ Sci. 2021;755(1). 
7. Roda R, Rodriguez A, Gomez A, Hernandez G, Iniesta F. Synergistic Antimicrobial Activities of Combinations of Vanilin and Essential Oils of Cinnamon Bark, Cinnamon Leaves, and Cloves. Foods. 2021;1-17.

8. Puspita W, Puspasari H, Restanti NA. Formulation And Physical Properties Test Of Spray Gel From Ethanol Extract Of Buas Buas Leaf (Premna Serratifolia L.). J Ilm Farm Bahari. 2020;11(2):145-52.

9. Faizah M, Sutiningsih. Pengaruh Formulasi Sediaan Facial Spray Gel Ekstrak Etanol 70 \% Kulit Buah Pisang Nangka ( Musa AAB ) Terhadap Sifat Fisik, Stabilitas Fisik dan Aktivitas Antioksidan. Indones Nat Res Pharm J. 2019;4(2):85-100.

10. Farnsworth NR. Biological and Phytochemical Screening of Plants. Pharm Sci. 1966;55.

11. Kristiningrum N, Hernawati S, Aulia RP, Wardani P. Studi Aktivitas Antioksidan Kombinasi Ektrak Etanol Daun Mangga Bachang (Mangifera foetida Lour.) dan Kelopak Bunga Rosella (Hibiscus sabdariffa L.). Semin Nas Pendidik Biol dan Saintek III. 2018;40-6.

12. Fitriansyah SN, Wirya S, Hermayanti C. Formulasi dan Evaluasi Spray Gel Fraksi Etil Asetat Pucuk Daun Teh Hijau (Camelia sinensis) sebagai Antijerawat. Pharmacy. 2016;13(02):203-16.

13. BPOM RI. Peraturan Badan Pengawas Obat dan Makanan Republik Indonesia Nomor 7 Tahun 2014 tentang Pedoman Uji Toksisitas Nonklinik Secara In Vivo. 2014;

14. Albab U, Nirwana RR, Firmansyah RA. Aktivitas Antioksidan Daun Jambu Air (Syzygium Samarangense (BI.) Merr Et. Perry) Serta Optimasi Suhu Dan Lama Penyeduhan. Walisongo J Chem. 2018;1(1):18.

15. Ali A, Chong $\mathrm{CH}$, Mah SH, Abdullah LC, Choong TSY, Chua BL. Impact of storage conditions on the stability of predominant phenolic constituents and antioxidant activity of dried piper betle extracts. Molecules. 2018;23(2).

16. Novak-Bilić G, Vučić $M$, Japundžić I, Meštrović-štefekov J, Stanić-Duktaj S, Lugović-Mihić L. Irritant and allergic contact dermatitis - skin lesion characteristics. Acta Clin Croat. 2018;57(4):713-20.

17. Kurniasari F, Widyasti JH. Uji Iritasi dan Uji Sifat Fisik Sediaan Gel Minyak Atsiri Daun Cengkeh (Syzygium aromaticum (L.) Merr. \& L.M.Perry) dengan Variasi Konsentrasi HPMC. Pharm J Farm Indones (Pharmaceutical J Indones. 2020;17(1):187.

18. yuliani et al. 2016. Uji Iritasi Sediaan Gel Penyembuh Luka Ekstrak Etanol Daun Binahong Menggunakan Slug Irritation Test. J Ilmu Kefarmasian Indones [Internet]. 2016;14(2):135-40. Available from: http://jurnalfarmasi.or.id/index.php/jifi/article/view/22 
19. Goossens A. Cosmetic contact allergens. Cosmetics. 2016;3(1):1-11.

20. Zlabiene U, Baranauskaite J, Kopustinskiene DM, Bernatoniene J. In vitro and clinical safety assessment of the multiple w/o/w emulsion based on the active ingredients from rosmarinus officinalis I., avena sativa I. and linum usitatissimum I. Pharmaceutics. 2021;13(5). 